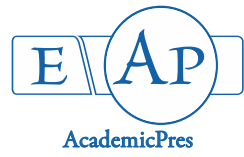

\title{
Effects of Organic Mulch Materials on Soil Surface Evaporation
}

\author{
Kingsley Chinyere UZOMA*, Brown Mang ONWUKA
}

\author{
Michael Okpara University of Agriculture, Department of Soil Science and Meteorology, Umudike, Abia State, \\ Nigeria; kingsolisis@yahoo.com (*correspondingauthor);onwuka.brown@mouau.edu.ng
}

\begin{abstract}
The effects of organic mulching material on soil surface evaporation were studied in Abia State. The objective of the study was to compare impact of mulch materials on saturated hydraulic conductivity and surface evaporation. The organic mulch materials were composted and non-composted Calapogonuim, Chromolena and Panicum spp. The design was randomized complete block design (RCBD). Data generated were statistically analysed. Analysis of variance was used to compare the influence of mulch materials on the measured soil properties and significant means were separated using least significant differences at $5 \%$ level of probability. Line graph was used to represent the impact of mulch materials on the surface evaporation. Results showed that saturated hydraulic conductivity of the soils increased significantly $(P \leq 0.05)$ with the application of the mulch materials. Soil applied with non-composted Chromolena spp. mulch material had the highest saturated hydraulic conductivity $\left(73.00 \mathrm{~cm} \mathrm{hr}^{-1}\right)$. Soil surface evaporation varied with both composted and non-composted mulch materials at $3^{\text {rd }}$ and $9^{\text {th }}$ day. The volume of soil moisture lost to the atmosphere was lower in non-composted Calapogonuim mulch material compared with the other mulch materials under study $\left(3^{\text {rd }}\right.$ to $9^{\text {th }}$ day, 3.9 to $11.0 \mathrm{~cm}^{3}$ respectively). Composted and non-composted Panicum mulch was observed to be a more efficient physical barrier to prevent the loss of moisture to the atmosphere as compared to other mulch materials studied. From the present study, it was evident that application of mulch reduced the actual evaporation rates in the initial days after irrigation (coinciding with early periods of plant growth). The water was thus conserved and could be used by the crop subsequently during the later period of its growth.
\end{abstract}

Keywords: irrigation; organic mulch; saturated hydraulic conductivity; soil moisture; soil surface evaporation

\section{Introduction}

Enhancing the efficiency of water for agricultural production is an ongoing objective that is geared towards achievement where water resources are limited and regulated in Nigeria. The limited water resources might be a result of its increasing demand generated by the growing population. The demand and use of water by the increasing population are essentially fixed and rising, so water availability for farmers is constantly reduced. The reduction in water availability can also be attributed to soil surface evaporation (Yuan et al., 2009). Evaporation from the soil surface significantly affects crop water use efficiency (McMillian, 2013).
Soil surface evaporation is energy activated process whereby soil water move up to the top soil layer and diffuse into the air in the form of vapour (Yuan et al., 2009). Evaporation rate is reduced in proportion to the water available to the soil surface (Allen et al., 1998). Mulching is a common and effective practice which can be used to address the problem of water loss through soil surface evaporation (Xie et al., 2005). The soil surface evaporation rate in relationship with time was studied by Diaz et al. (2005) to address the effects of gravel mulches on soil surface evaporation. The atmospheric evaporation was also measured by Yuan et al. (2009), which was used as comparative values of the soil surface evaporation to show the effects of mulch on evaporation. Demir et al. (2009) observed that application of organic based mulches to the soil surface reduced evaporation, increased organic matter and changed the soil properties. Unger and Panker (1976) also reported a decreased evaporation rate for mulched plots but only approximately 15 days after water was introduced into the plots. The type, amount, thickness, size of mulching materials and the atmospheric evaporative demand determine the rate of soil drying (Tolk et al., 1999). 
388

In recent time, agricultural productivity in the study area have been on the decline due to high rate of water loss from the soil arising from direct heat of solar radiation without a corresponding soil management system. It is therefore important to ascertain the effect of material and thickness on soil surface evaporation and water conservation in the soil of the study area. This will probably enhance the soil water retention capacity and productivity of the soils in the area. The objective of the study was to compare the effects of organic mulch materials on the saturated hydraulic conductivity and surface evaporation of the soil.

\section{Materials and Methods}

\section{Experimentalmaterials}

Soil evaporation was estimated with different organic mulching materials in the laboratory condition. Soil samples were collected from the experimental site of Michael Okpara University of Agriculture Umudike Eastern farm, at different sampling units, with a soil auger. Mulch materials used for the experiment were: Calapogonuim spp., Chromolena spp. and Panicum spp. The evaporation metallic cylinders were $6 \mathrm{~cm}$ in diameter and $30 \mathrm{~cm}$ in height.

\section{Experiment}

Soil evaporation from a saturated soil placed in a metallic cylinder closed at the bottom and covered with mulching materials was measured by weighing periodically the cylinder with a weighing balance. The cylinder was located in a room maintained at constant air temperature $\left(28{ }^{\circ} \mathrm{C}\right)$ and air humidity $(60 \%)$. The first half of the cylinder was filled with $4.8 \mathrm{~g}$ of soil, while the other half was filled with composted and non-composted mulch material rates of $1.2 \mathrm{~g}$ and $2.4 \mathrm{~g}$ each. The required amount of water was evenly added to bring it up to saturation. The cylinder was weighed the first day of trial just after the addition of the mulch materials over the saturated soil. The weight was measured 1 day after the experiment was set up and daily thereafter at $9.00 \mathrm{am}$.

\section{Laboratory analysis}

Particle size distribution was determined using the Bouyoucos hydrometer method as simplified by Kettler $e t$ al. (2001). Saturated hydraulic conductivity (Ksat) was determined by the constant head permeameter method (Stolte, 1997).

\section{Statistical analysis}

Collecting data: soil moisture loss was monitored everyday beginning from 1 day after saturation and ending on the $9^{\text {th }}$ day. This was accomplished by subtracting the total weight of the container at a particular time from the original to determine total soil moisture loss from that period of time.

The changes in weight of the evaporation cylinder measured everyday were recorded as soil surface evaporation volumes (g/day).

The soil surface evaporation volume was converted to soil surface evaporation using the model described Yuan et al. (2009).

$$
\begin{aligned}
& \text { Ess }=\frac{E m s \times\left(1000 \mathrm{~cm}^{3} \mathrm{~kg}^{-1}\right) \times\left(10 \mathrm{~mm}^{-1} \mathrm{~cm}^{-1}\right)}{A \text { soil }} \\
& \text { Where: } \begin{array}{c}
\text { Ess }=\text { soil surface evaporation } \\
\text { Ems = soil surface evaporation volume } \\
\text { A soil = surface area of soil. }
\end{array}
\end{aligned}
$$

Data analysis: the data collected were subjected to analysis of variance (ANOVA) in a randomized complete block design. The means were separated using Fishers least significant difference at $0.05 \%$ probability.

Line graph was used to represent the impact of mulch materials on the surface evaporation.

\section{Results and Discussion}

\section{Particle size distribution}

The particle size distribution of the soil studied is shown in Table 1. The results showed that among the treatments the non-mulched soil recorded the highest sand content $(885.3 \mathrm{~g} / \mathrm{kg})$, while non-composted Chromolena mulch recorded the lowest sand content $(875.3 \mathrm{~g} / \mathrm{kg})$. The sand contents of the treatments were statistically $(\mathrm{P} \leq 0.05)$ similar. The highest silt content of $65.3 \mathrm{~g} / \mathrm{kg}$ was observed in non-composted of both Chromolena and Calapogonuim mulch materials. However, composted Calapogonuim recorded the lowest silt content of $58.7 \mathrm{~g} / \mathrm{kg}$. Noncomposted Chromolena had the highest clay content (59.4 $\mathrm{g} / \mathrm{kg}$ ) and non-mulched soil had the lowest clay content $(52.7 \mathrm{~g} / \mathrm{kg})$. The clay content of the mulched soils were statistically $(\mathrm{P} \leq 0.05)$ similar with one another, but statistically different from the non-mulched soil. The sandy nature of the soil was attributed to their being derived from unconsolidated sand deposit formed over coastal plain sand and sedimentary rock (Chukwu, 2012).

Table 1. Particle size distribution of soils studies

\begin{tabular}{ccccc}
\hline & Sand $(\mathrm{g} / \mathrm{kg})$ & Silt & Clay & TC \\
\hline Control & 885.3 & 62.0 & 52.7 & Loamy sand \\
Panicum spp. $(\mathrm{CM})$ & 882.0 & 62.0 & 56.0 & Loamy sand \\
Panicum spp. (NCM) & 882.0 & 62.0 & 56.0 & Loamy sand \\
Chromolena spp. (CM) & 882.0 & 62.0 & 56.0 & Loamy sand \\
Chromolena spp. (NCM) & 875.3 & 65.3 & 59.4 & Loamy sand \\
Calapogonuim spp. $(\mathrm{CM})$ & 882.0 & 58.7 & 59.3 & Loamy sand \\
Calapogonuim spp. (NCM) & 878.7 & 65.3 & 56.0 & Loamy sand \\
\hline LSD0.05 & 11.5 & 7.5 & 12.1 & \\
\hline
\end{tabular}


Effects of mulch materials on saturated hydraulic conductivity

The effects of mulch materials and treatments on the saturated hydraulic conductivity of soil studied are shown in Table 2. The data showed that the soil applied with noncomposted Chromolena spp. mulch material had the highest saturated hydraulic conductivity $\left(73.00 \mathrm{~cm} \mathrm{hr}^{-1}\right)$, whereas control had the lowest $\left(26.14 \mathrm{~cm} \mathrm{hr}^{-1}\right)$. Generally, the saturated hydraulic conductivity of the soils (Tables 2) increased significantly $(\mathrm{P} \leq 0.05)$ with the application of the mulch materials. As shown in Table 2 and with reference to the control, the saturated hydraulic conductivity of the soil after treatment with mulch materials was significantly $(\mathrm{P} \leq$ $0.05)$ higher than the control. With reference to the mulch materials and mulch treatments, the values indicated that the saturated hydraulic conductivity was significantly $(\mathrm{P} \leq$ $0.05)$ similar. This result showed that the mulch materials increased the movement of water along a hydraulic gradient.

The significantly $(\mathrm{P} \leq 0.05)$ higher saturated hydraulic conductivity obtained in the soils due to the application of mulch could be attributed to improvement in soil porosity (not analysed) as a result of mulching (Kakaire et al., 2015). Mulching increased the soil porosity which in turn led to significant improvement in the saturated hydraulic conductivity. The larger the soil pores, the more water is easily transmitted through the soils (Papadopoulos et al., 2006).These findings are in agreement with those of Dec et al. (2008). Gulser and Candemir (2014) also reiterated that saturated hydraulic conductivity is largely associated with the soil porosity and pore size distribution. The higher Ksat of the mulched soil may be attributed to the ability of mulch materials to increase peculation and water retention (Rar and Singh, 2004). This observation was in line with the findings of Bhart and Kherg (2006) who recorded that Ksat was higher in mulched soil than the bare soil.

\section{Effects of mulch materials on soil surface evaporation}

The volume of soil water content lost to the environment under the three mulch treatments during evaporation period is shown in Figs.1 - 3. As the soil was fully saturated, there was no significant difference in the volume of soil water loss among the different mulch treatments during initial stage of observation. However with passage of time, volume of soil moisture loss changed, resulting in significant variation in soil water loss among no mulch (NM), non-composted mulch (NCM) and composted mulch (CM). With regards to Calapogonuim mulch, the volume of soil water lost in soil with noncomposted mulch (NCM) increased from 3.9 to $11.0 \mathrm{~cm}^{3}$ in 3 to 9 days after saturation, whereas these values were 4.0 to $11.1 \mathrm{~cm}^{3}$ and 8.1 to $15.0 \mathrm{~cm}^{3}$ for composted mulch (CM) and no mulch (NM), respectively (Fig. 1). Under Chromolena mulch, the flux in volume of soil water lost in non-composted (NCM) increased from 4.9 to $12.2 \mathrm{~cm}^{3}$ from 3 to 9 days after saturation, whereas such increase were from 5.4 to $12.0 \mathrm{~cm}^{3}$ and from 8.1 to $15.0 \mathrm{~cm}^{3}$ for compost mulch (CM) and no mulch (NM), respectively (Fig. 2). With reference to Panicum mulch, the volume of soil water lost in soil with non-composted mulch (NCM) increased from 4.4 to $11.9 \mathrm{~cm}^{3}$ from 3 to 9 days after saturation, whereas such increase were from 4.9 to $11.9 \mathrm{~cm}^{3}$ and from 8.1 to $15.0 \mathrm{~cm}^{3}$ for compost mulch (CM) and no mulch (NM), respectively (Fig. 3).

These indicate that the soil surface evaporation flux was affected by the moisture conserving capacity of the mulches (Kakaire et al., 2015). There was no significant initial variation in moisture content among the mulching treatments, but with time, the depletion of moisture content increased, which was maximum in soil with no mulch (NM), followed by non-composted mulch (NCM) and composted mulch (CM), possibly due to moisture conservation potential of NCM and CM. As a result of this, the variation of flux values among different treatments became significant in time.

The volume of soil water lost to the environment from different mulch treatments followed a common trend with time after saturation. But the range of increase in volume of soil water content lost was different from one treatment to another. In non-composted mulch (NCM), compared to the control (NM), water depletion between 1 and 9 days after saturation was 20\% less in Calapogonuim mulched soil (Fig. 1i), 28\% less in Chromolena mulched soil (Fig. 2i) and $30 \%$ less in the Panicum mulched soil (Fig. 3i). Treatments recorded 21\% (Fig. 1ii), 28\% (Fig. 2ii) and 31\% (Fig.3ii) less depletion between $1-9$ days after saturation for composted mulch treatments of Calapogonuim, Chromolena and Panicum, respectively, compared to control (NM). However, no significant differences in water depletion were observed between the treatments (Fig. 1iii, Fig. 2iii and Fig. 3iii).

Table 2. Effects of mulch materials and treatment on saturated hydraulic conductivity of soil studied

\begin{tabular}{|c|c|c|c|c|}
\hline \multirow{2}{*}{ Mulch materials } & \multicolumn{4}{|c|}{ Mulch treatments } \\
\hline & Composted & Non-composted & Mean & LSD \\
\hline Control & 26.14 & 26.14 & 26.14 & 0.04 \\
\hline Panicum spp. & 72.71 & 72.56 & 72.64 & 1.05 \\
\hline Calapogonuim spp. & 72.76 & 72.53 & 72.66 & 1.15 \\
\hline Chromolena spp. & 72.90 & 73.00 & 72.95 & 1.34 \\
\hline Mean & 61.13 & 61.06 & & \\
\hline \multicolumn{5}{|l|}{$\mathrm{LSD}_{0.05}$} \\
\hline Mulch materials & 4.87 & 4.01 & & \\
\hline Materials $\times$ treatments & 2.74 & 5.07 & & \\
\hline
\end{tabular}




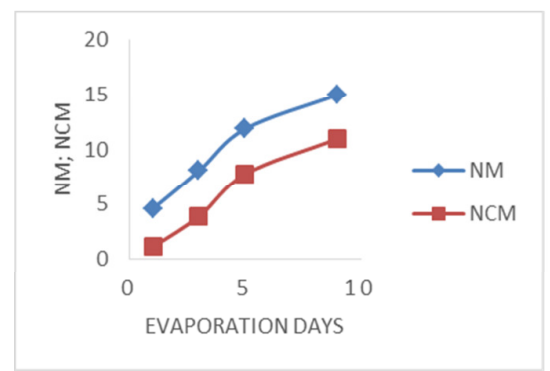

(i) Non composted mulch

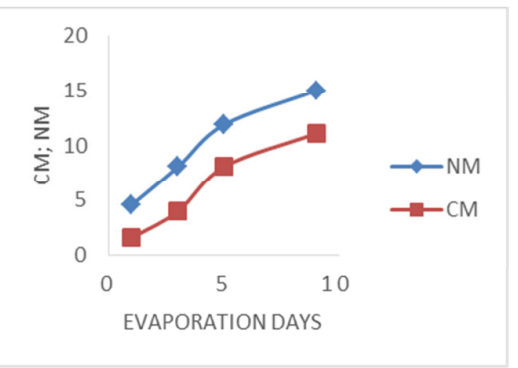

(ii) Composted mulch

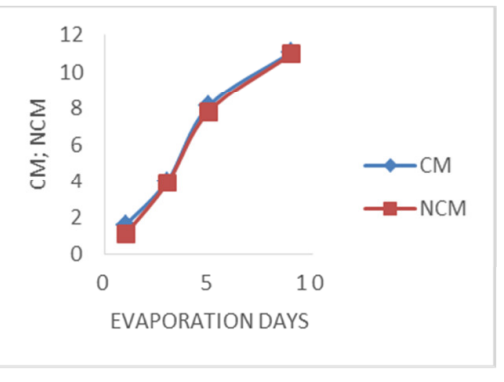

(iii) Comparison between composted and non composted mulch

Fig. 1. Effects of Calapogonuim mulch material on soil evaporation

$\mathrm{NM}=$ No mulch; $\mathrm{NCM}=$ non - composted mulch; $\mathrm{CM}=$ composted mulch

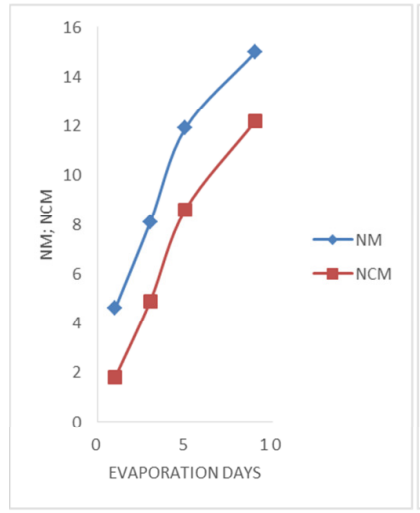

(i) Non composted mulch

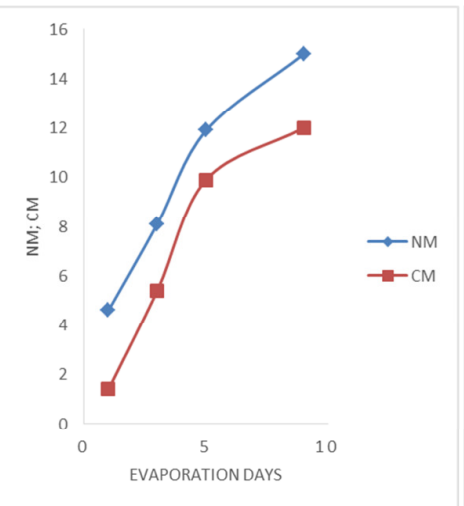

(ii) Composted mulch

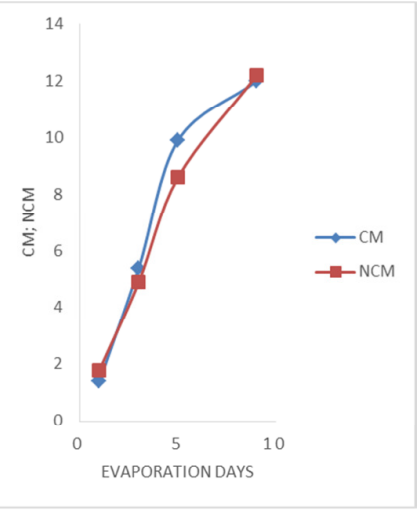

(iii) Comparison between composted and non composted mulch

Fig. 2. Effects of Chromolena mulch material on soil evaporation

$\mathrm{NM}=$ No mulch; $\mathrm{NCM}=$ non- composted mulch; $\mathrm{CM}=$ composted mulch

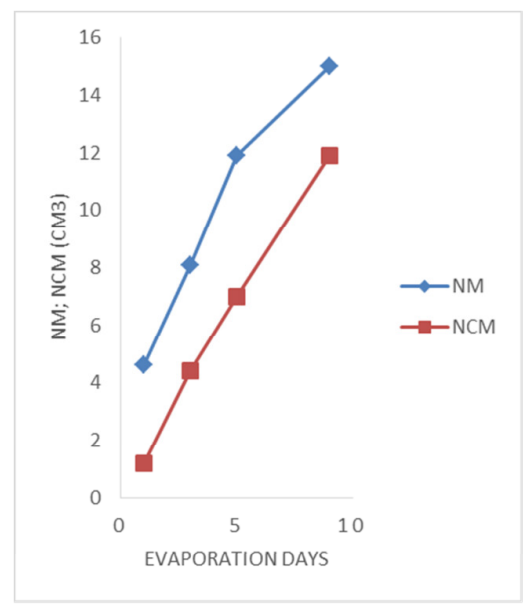

(i) Non composted mulch

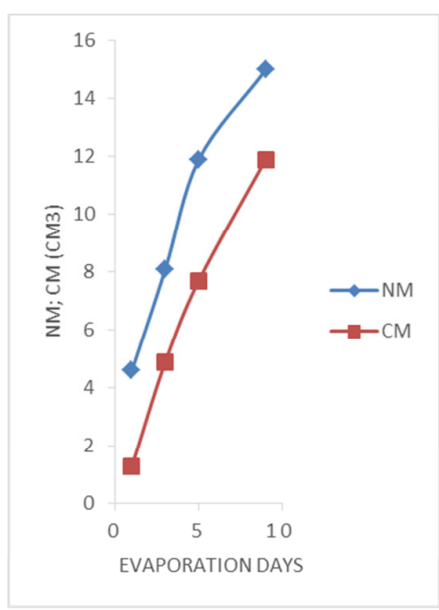

(ii) Composted mulch

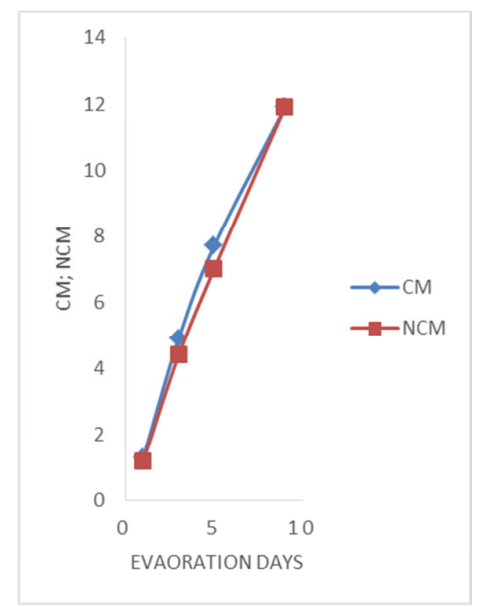

(iii) Comparison between composted and non composted mulch

Fig. 3. Effects of Panicum mulch material on soil evaporation

$\mathrm{NM}=$ No mulch; $\mathrm{NCM}=$ non - composted mulch; $\mathrm{CM}=$ composted mulch 
Under no mulch, the volume of soil water content lost to the environment increased sharply from the $3^{\text {rd }}$ day after saturation. This observation is in line with the findings of $\mathrm{Li}$ (2003). The reduction in soil water loss through evaporation, when the soil surface was mulched, could be attributed to the reduction in amount of sun light heating the soil (Xie et al., 2005). The mulch materials also maintained humidity rate at the soil surface and prevents air flow which keeps the moisture in the soil. Under noncomposted Calapogonuim mulch, surface evaporation was reduced more than others due to the protection and isolation of soil surface from insolation, interruption in downward heat flow and obstruction to the diffusion of vapour (Li et al., 2001).

Panicum spp. mulch was less effective than the other mulch materials because whatever amount of water vapour was formed, it could escape through the porous layer, which was not possible in case of Calapogonuim and Chromolena (Nwokeocha et al., 2007). Similar results were also reported earlier by Kumara and Dey (2011).

\section{Conclusions}

The effects of organic mulching material on soil surface evaporation were studied with the objective to compare impact of mulch materials on saturated hydraulic conductivity and surface evaporation. The results indicated that the mulch materials were effective in improving the saturated hydraulic conductivity of the soil. All mulching materials (both composted and non-composted) decreased soil evaporation in the energy-limited stage in relation to the bare soil. The average daily soil evaporation rates (ER) were significantly different $(\mathrm{P} \leq 0.05)$ among all mulching treatments, with the highest evaporation rate decrease in non-composted Calapogonuim spp. and the lowest evaporation rate decrease in bare soil. During the falling-rate stage where evaporation is controlled by soil water content, the evaporation rates were low and similar among treatments, suggesting that soil mulching will be inefficient for soil evaporation control in low-frequency irrigation systems where the soil remains dry most of the time. During the energy-limited stage, both composted and noncomposted Panicum, Calapogonuim and Chromolena mulch materials were most effective for evaporation control. These materials will be therefore recommended in highfrequency irrigation systems because of the high and almost continuous wetting of the soil surface in these systems.

\section{References}

Allen RG, Pereira LS, Raes D, Smith M (1998). Crop evapotranspirationguidelines for computing crop water requirements-FAO irrigation and drainage paper 56. Fao, Rome, 300(9):D05109.

Bhart R, Khera KC (2006). Effect of tillage and made of straw mulch application on soil erosion in the submontaneous trout of Punjab, India Soil and Tillage Research 88(1-2):107-115.

Chukwu GO (2012). Soil survey and classification of Ikwuano, Abia state, Nigeria. Journal of Environmental Science and Water Resources 2(5):150-156.
Dec D, Dornerl J, Becker-Fazekas O, Horn R (2008). Effect of bulk density on hydraulic properties of homogenized and structured soils. Revista de la Ciencia del Sueloy Nutrición Vegetal 8(1):1-13.

Demir Z, Yildiz O, Toprak B (2009). Water retention ratios of mulching material consisting primarily of pine bark over different soil types. Pakistan Journal of Botany41(4):1851-1859.

Diaz F, Jimenez CC, Tejedor M (2005). Influence of the thickness and grain size of tephra mulch on soil water evaporation. Agricultural Water Management 74(1):47-55.

Gülser C, Candemir F (2014). Using soil moisture constants and physical properties to predict saturated hydraulic conductivity. Applied Ecology andEnvironmental Sciences 3(1):77-81.

Kakaire J, Makokha GL, Mwanjalolo M, Mensah AK, Menya E (2015). Effects of mulching on soil hydro-physical properties in Kibaale subcatchment, South Central Uganda Applied Ecology and Environmental Sciences 3(5):127-135.

Kettler TA, Doran JW, Gilbert TL (2001). Simplified method for soil particle-size determination to accompany soil-quality analyses. Soil Science Society of America Journal 65(3):849-852.

Kumara S, De P (2011). Effects of different mulches and irrigation methods on root 254 growth, nutrient uptake, water-use efficiency and yield of strawberry.Scientia Horticulturae 127(3):318-324.

Li XY, GongJD, Gaq QZ, Li FR (2001). Incorporation of ridge and furrow method of rainfall harvesting with mulching for crop production under semiarid conditions. Agricultural Water Management 50(3):173-183.

$\mathrm{LiXY}$ (2003). Curarel-sand mulch for soil and conservation in the semi-arid loess region of northwest China Catena 52(2):105-127.

McMillian M (2013). The effect of mulch type and thickness on soil surface evaporation rate. Horticulture and Crop Science Department, California Polytechnic State University, San Luis Obispo.

Nwokocha C, Olojede A, Mbagwu J (2007). Mulching an arenic hapludult at Umudike: Effects on saturated hydraulic conductivity and rhyizome yield of turmeric. African Journal of Biotechnology 6(17).

Papadopoulos A, Mooney SJ, Bird NRA (2006). Quantification of the effects of contrasting crops in the development of soil structure: an organic conversion. Soil Use and Management 22(2):172-179.

Rar G, Singh R (2004). Soil nature retention-transition studies and enhancing water use efficiency of winter crops through soil surface modification. Indian Journal of Soil Conservation 8:18-23.

Stolte J (1997). Manual for soil physical measurements, version 3. Wageningen DLO Winand Starring Centre for Integrated Land. Soil and Water Research, Technical Document 37.

Tolk JA, Howell TA, Evett SR (1999). Effect of mulch, irrigation and soil type on water use and yield of maize. Soil Tillage Research 50(2):137147.

Unger PW, Parker JJ (1976). Evaporation reduction from soil with wheat, sorghum, and cotton residues. Soil Science Society of America Journal 40(6):938-942.

Xie ZK, Wang YJ,Jiang WL (2005). Evaporation and evapotranspiration in a watermelon filled mulched with gravel of different size in northwest china. Agricultural Water Management 81(1-2):173-184.

Yuan C, Lei T, Mao L, Liu H, Wu Y (2009). Soil surface evaporation processes under mulches of different sized gravel. Catena 78(2):117-121. 